\title{
Consideration on fastening force for plates by head in riveting
}

\author{
○正 木之下 広幸（宮崎大） 正 海津 浩一（宮崎大） \\ Hiroyuki Kinoshita, Koichi Kaizu \\ 1-1, Gakuen kibanadai nishi, Miyazaki University of Miyazaki
}

Key Words : Fixing Element, Riveting Process, Joint Strength, Springback, FEM

\section{1.はじめに}

リベット締結は, 近年の省力化, コストダウン化の要望 とともに，電子部品や自動車用部品などへの適用が増加す る傾向にある(1).しかし，板の緩みが製品に及ぼす影響が 問題となることがあり，板の緩みの無い加工法の開発が望 まれている，板が緩む原因には，過度の加圧力によって生 じる板の反りとリベット頭部による板の締付け力の不足が 考えられる，板の反りに関しては，その発生機構が，近藤 らによる研究 ${ }^{(2)}$ で調査・検討されている.

リベットの頭部による板の締付け力の不足に関しては, 板がリベット材と比較して相対的に硬い場合に生じやすい と考えられる。なぜなら，この場合の板の締結は，主にリ ベットの軸部と板の結合力でなされており，頭部による板 の締付け力が，非常に小さいからである。このことは，著 者らの板の引抜き試験の結果 ${ }^{(3)}$ から明らかにされている。 この原因は，リベットのスプリングバックが板のスプリン グバックよりも大きくなるためと考えられる.

以上のことから，リベットの加工力を小さくすることが 板の反りを無くし；頭部による板の締付け力を高めること に繫がると考えられる.

本研究では, 単純な据込み加工でリベットを成形する場 合を対象として，リベットの加工力を小さくし，頭部によ る板の締付け力を高めることを目的に，チューブラリベッ 卜を応用した加工法を提案し, 実験および有限要素解析に よりその有効性を検討した.

\section{2. チューブラリベットを応用した加エ法}

2.1 リベットの加工方法の概要 Fig.1 に, 提案する 加工法の有限要素計算モデルを示す. リベットのタイプに 関しては，丸などの形に頭部を成形するよりも平タイプに 成形した方がスプリングバックは小さくなる ${ }^{(3)}$. そこで, 提案する加工法では，リベット材の中心部に寉みを設け, これを平タイプのパンチを用いて, 成形後の頭部がちょう ど平頭になるように成形するものとする（以後，このタイ プを Flat IIタイプと呼ぶ).

なお，リベット材の寸法・形状は，突出部の体積が，平 タイフプ突出部の体積と等しくなるように決定するものと し, 同計算モデルは, 中心部に乼みを設けた分, 高さを増 している、また, 窪み底部の角部には加工中にき裂が生じ ないように面取りまたは丸みを設けることとする.さらに， パンチとリベット材の接触面がリング状であるので, リン グ部の内側への折込みが生じないように，接触面の潤滑状 態を良好にして摩擦力を小さくし，リング部が外側に広が るように加工するものとする。

2.2 有限要素計算によるリベットのスプリングバック の解析 先ず, 以上の加工法によるリベットの成形の可
Table 1 Computational condition

\begin{tabular}{l|l}
\hline \hline Young's modulus : E $(\mathrm{GPa})$ & Aluminum alloy :A1070:68.6 \\
\hline Poisson's ratio $: v$ & 0.3 \\
\hline Yield stress $: \sigma_{0}(\mathrm{MPa})$ & 18.819 \\
\hline Flow stress $(\mathrm{MPa})$ & $\bar{\sigma}=119.92(0.002+\bar{\varepsilon})^{0.298}$ \\
\hline
\end{tabular}

能性, および加工力と除荷後に生じるスプリングバックを どの程度減じることができるかについて検討するため，リ ベットの加工過程の有限要素解析を行った.

有限要素計算には，負荷過程の計算および除荷の計算之 もに，静的陽解法の弾塑性有限要素法 ${ }^{(4)}$ を用いた。

Table1 に計算の条件を示す．計算は，軸対称問題として 行い, 要素剛性方程式の積分は, $2 \times 2$ の低減積分としてい る.また，除荷の方法には節点力法を用いた。

Fig.2 は, 突出部を $62 \%$ まで圧縮した場合の負荷の終了 時における変形した形状を示している.この図から, リベ ット材に滗みが無い場合と同様に，板は角部から徐々に接 合され，軸中心部を直接圧縮すること無しに，フラットタ イプの形状とほぼ同じ形状が得られることがわかる。

Fig.3 は, リベットのスプリングバックを比較している. なお，これらの図は，負荷の終了時に板上面に接していた 節点の除荷後の軸方向の変位をスプリングバックとして示 している. 本タイプの節点の変位量は, フラットタイプの 7 割程度に減少していることがわかる。

\section{3. 板の引抜き試験による締付けカの評価}

3.1 板の引抜き試験の方法惢ット頭部による板 の締付け力を評価するために，板の引抜き試験を行った。 Fig.4に, 板の引抜き試験の概要を示す. 同試験は, 引抜き 可能な板を締結した後に, 板の両端の引張試験を行い, そ の板の引拔き時における最大引張力の大きさから，リベッ ト頭部による板の締付け力を評価することを意図している. 実験は，板がリベット材と比較して相対的に硬くリベット 締めした後も板は塑性変形しない場合について行った，先 ず，リベット材に，アルミニウム合金 A1070材を用い，直 径 $13 \mathrm{~mm}$, 長さ $44 \mathrm{~mm}$ （Flat II タイプは，45mm）の棒状試験片 から，Fig.4(A)に示す実験装置を用いて，丸，なべ，平夕 イプ，および Flat II タイプの各リベットを据込み加工によ り製作した。次に，Fig.4(B)に示すように，一般構造用圧 延鋼材 (SS400)の 2 枚の板を重ねて締結した。 その際, 締結 した板を引抜くことができるように，2 枚重ねの下側の板 には，中心軸を含む断面で 2 分割した板を用いた．また， 板の締結は, 分割板が開かないように両端を固定して行っ た. 分割板の寸法は, 幅 $50 \mathrm{~mm}$, 長さ $44 \mathrm{~mm}$, 厚さ $9 \mathrm{~mm}$ で, 上側 の一枚板の寸法は, 幅 $50 \mathrm{~mm}$, 長さ $40 \mathrm{~mm}$, 厚さ $9 \mathrm{~mm}$ である. リ. ベット穴の径は， $\phi 14 \mathrm{~mm}$ としている，板の引抜き試験は， 


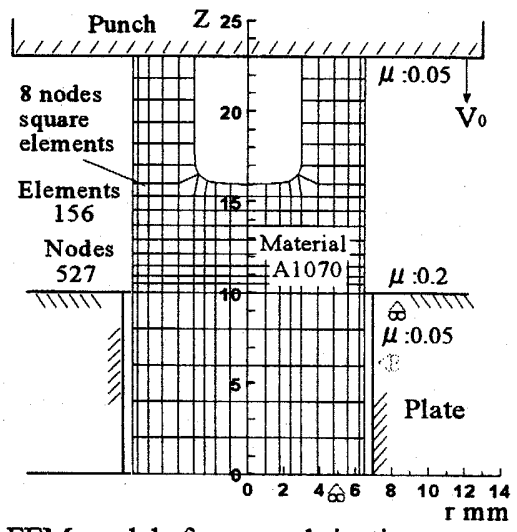

Fig. 1 FEM model of proposed riveting process

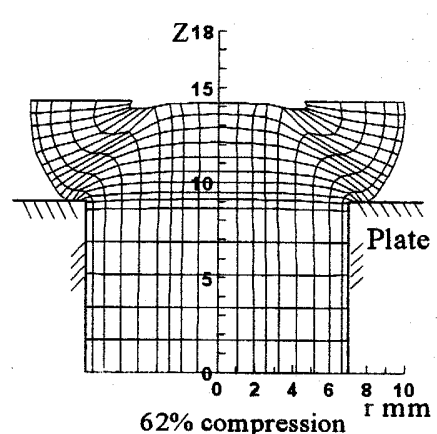

Fig.2 Deformed shape
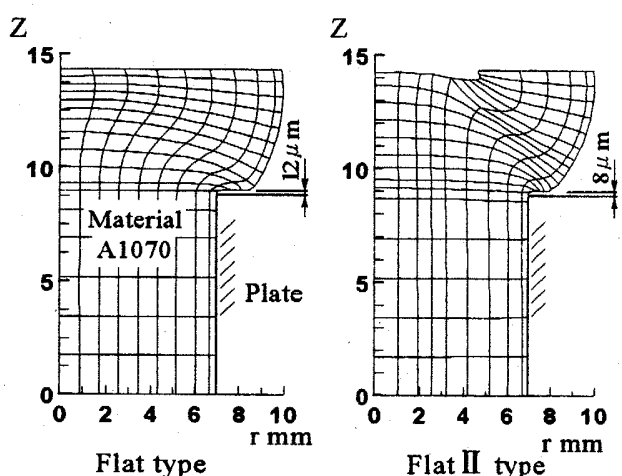

Fig. 3 Comparison of springback of rivet

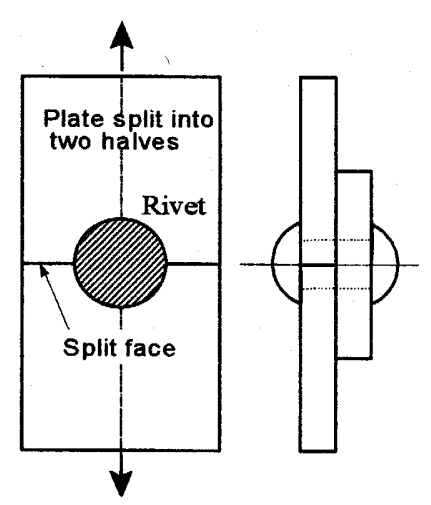

(C) Disjointing test

Fig.4 Schematic illustration of the disjointing test

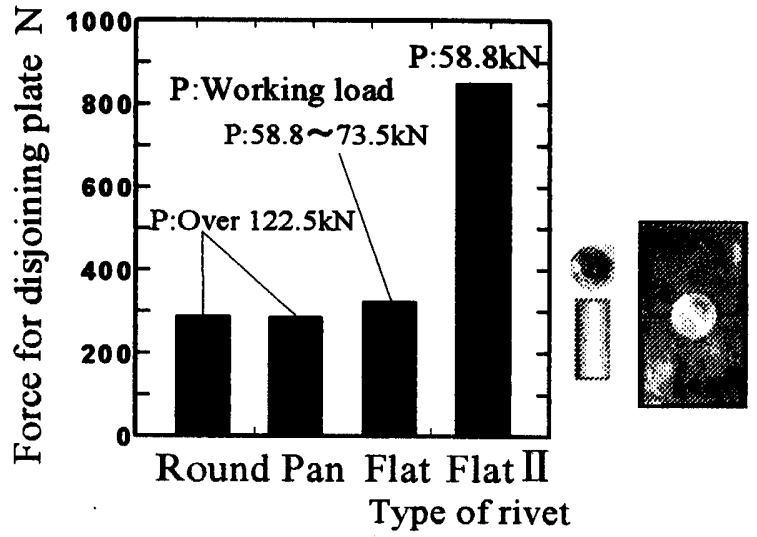

Fig. 5 Comparison of disjoining force for plate

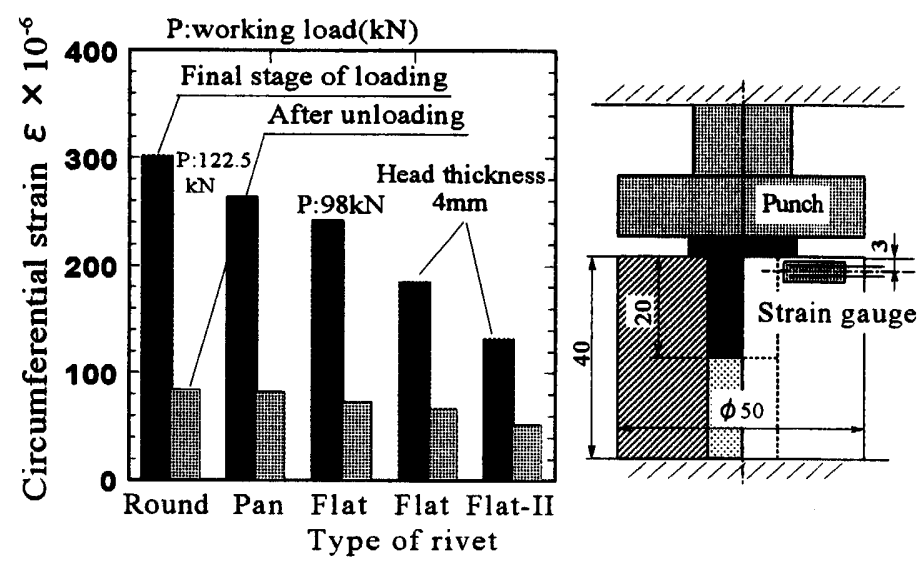

Fig.6 Comparison of strain around rivet axis
Fig.4 (C)に示すように締結した分割板の両端をオートグラ フで引張ることにより行った。

\section{4. 結果および考察}

Fig.5 は, 予め棒状試片の一端を平頭に成形したりベット

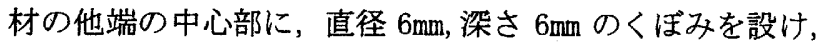
3.1 項で述べた板の引抜き試験を行った結果を示している. 板の引抜き試験は, 各タイプに関して, 各々 $5 \sim 8$ 回行い, 図はそれらの平均值を比較して表している，この図から， Flat II タイプの板の引抜きカが他のタイプよりも 2 倍以上 大きいことがわかる。このことから，提案した加工法が， 頭部による板の締付け力を高めるために有効な方法と考え られる。

Fig.6 は, リベットのスプリングバックの大きさを比較す るために，リベット軸周囲のひずみを測定した結果を示し
ている，ひずみの測定は，型の側面にひずみゲージを図に 示す位置に張り付け，リベット頭部の成形開始時から除荷 後までの間の型の円周ひずみを測定することにより行った. また，ひずみの測定結果の図において，除荷前後のひずみ の差がリベットのスプリングバックに相当している.この 図から, Flat II タイプのスプリングバックが, 他のタイプ よりも小さくなっていることが確認できる.

\section{参考文献}

（1）町田輝史他，塑性と加工，34-389（1993-6), 689-693.

（2）近藤一義，峯英生，村里共一，平成 6 年度塑性加工春期 講演会論文集 (1994-5), 461-464.

(3)H. Kinoshita, K. Kaizu, M\&P2005, (2005), ICS-04.

（4）日本塑性加工学会編 : 非線形有限要素法, (1994), 79, コロナ社。 